\title{
PROBLEMS AND PROSPECTS OF THE SHIPBUILDING AND SHIP REPAIR INDUSTRY DEVELOPMENT IN THE RUSSIAN FAR EAST: THE HISTORICAL ASPECT
}

\author{
Komissarova V.V., Lecturer \\ Vladivostok State University of Economics and Service, Vladivostok, Russia \\ E-mail: valeriya.komissarova@vvsu.ru
}

\begin{abstract}
The article is devoted to the analysis of problems and prospects for the shipbuilding and ship repair industries development in the Far Eastern Federal District, in general, and Primorsky Krai, in particular. Quality of shipbuilding development reflects scientific and technical development level of the country. During all historical periods the shipbuilding of Russia depended on foreign technologies and ship equipment import. Since the beginning of the industry the state has been the large owner of assets, defining a strategy of development and carrying out the control functions. In pre-revolutionary Russia private shipbuilding companies had been founded with participation of banking capital including foreign capital. During the Soviet period the state administration reforms had been mainly directed on changing of institutional subordination of the industry enterprises. Science the beginning of 90 -s the governance system destruction led to crisis in the industry. So, between ship repair and the shipbuilding industry, production and information communications are not developed. This fact constrains the structure improvement of these industries, the joint development of their specialization and cooperation. The science serving shipbuilding and ship repair is also disunited - the scientific forces of the shipbuilding industry in the region were organized within their industry and have weak links with the corresponding repair organizations. Within the last several years the new governmental paradigm in the industry is being created. Today, there are a number of problems in the industry that require government intervention and private investment.
\end{abstract}

\section{KEY WORDS}

Shipbuilding, ship repair industries, gross regional product (GRP), international competition, centralized planning, support measures, world market.

Shipbuilding largely determines the national security of the state in all maritime activities spheres in Russia's Far East, including defense, transport, food, energy and technology. Shipbuilding has a multiplier effect, affecting the technology and production development in related industries and services.

The shipbuilding industry, being one of the most important branches of the national economy and possessing scientific, technical and production potential, has a decisive influence on many related sectors, on the economy of the country as a whole, on its defense capability and political position in the world. The state of shipbuilding reflects the level of scientific and technical potential of the country, accumulating in its products the achievements of metallurgy, engineering, electronics and advanced technologies. The problem of ensuring the marine shipbuilding competitive development in the Far Eastern Federal District (DFO) is now becoming particularly relevant. For the Far East, marine transport, shipbuilding and related economic activities are the priority areas of the economy. So, only nearly $20 \%$ of the gross regional product (GRP) of the Far Eastern Federal District accounts transports and logistics sector share only [1].

The shipbuilding industry has not been able to adapt to the new realities and the mechanisms and strategy question for the industry long-term development remains unresolved over the decades of Russia existence in a market economy. At the same time, being the most important stock-forming industry for all economies with marine specialization, shipbuilding and ship repair not only determine the level of technical progress in the country, but also the growth rate of the national economy. 
Currently, every fifth shipbuilding and ship repair company of the country is located in the Far Eastern Federal District, and Far Eastern enterprises account for more than $25 \%$ of the book value of fixed assets of this industry. At the same time, attention is drawn to the tendency of the lagging behind the Far Eastern shipbuilding and ship repair from the average Russian growth rates of production scales, which has been outlined in recent [1].

Main part. The shipbuilding development in USSR was one of the main segments of heavy industry, and strategically important. According to the directives of the Ministry of the Merchant Marine of the country, no less than half of the foreign trade cargoes had to service of national carrier's ships. Moreover, the fleet not only provided for the interests of trade, but also fulfilled international tasks (like delivering cargo to developing allied countries). The USSR developed its own industry in every possible way, as it could not afford dependence on foreign shipbuilders, who for political reasons could at any time refuse to cooperate with the country [2].

With the collapse of the Soviet Union, interior demand fell to almost zero, part of shipyards remained in the Baltic Countries and Ukraine, many ships were sold, and factories went bankrupt [3]. With the favorable oil situation beginning in the 2000s, the surviving domestic carriers "Sovkomflot», "Novoship» (which later became a subsidiary of «Sovkomflot»), the Primorsk Shipping Company and the Far Eastern Shipping Company, the question arose of replenishing the ship's fleet under the growing base, first of all - oil, oil products, grain, metals and containers.

The industry development strategy has been discussed for a long time in the government, until finally it became clear that without the unification of separate enterprises under one roof, the task of revival will not be solved. In 2007, the decree of the Russian president on the creation of the United Shipbuilding Corporation (USC) was signed. She received special powers from the authorities in the matter of asset consolidation, as well as support in the form of government-issued private orders to carriers to support orders for the company being created. Dmitry Medvedev being president (now vice minister) at one of the meetings devoted to the modernization of the country, listed several industries that, in his opinion, should become points of growth. They include production of military and civilian vessels [4].

Main feature of the world shipbuilding development current stage is the leading countries transition to a strategy based primarily on the generation, dissemination and use of the most advanced knowledge and technologies. Unique skills and abilities, ability to adapt them to constantly changing conditions of activity, high qualification become the leading production resource. Intensification of the shipbuilding production and use new scientific and technical results predetermined a sharp reduction of the innovation cycle, acceleration of the rates renewal of products and technologies. The modern experience in management of shipbuilding and ship repair in the framework of large corporations is based on close cooperation between ship repair and related shipbuilding enterprises. Manufacturers observe their vessels practically during their entire service life.

In Russia, the forms of management of shipbuilding and ship repair production were largely determined by both political and natural factors. Historically, in the Russian Far East, activities related to the reproduction of the fleet (metal vessels) began not with shipbuilding, but with repair enterprises. Ship repair production in the Far East appeared in the late nineteenth century. In the first years of its development, ship-repairing production was developing, mainly, to ensure the repair of ships of the Siberian Flotilla (later - the Russian Pacific Navy). The first ship-repair shop with a smithy was already laid in the year of foundation (in 1860) of Vladivostok military post. In the 1970s, on the bases of several shiprepair workshops, the Far Eastern mechanical breech-making plant (now «Dalzavod») began to be created. In the 90's in Vladivostok there were workshops for the repair of civilian vessels, eventually turned into a shipyard of the Voluntary Fleet (later plant $\mathrm{N}_{2}$ «Narkomflot»). In 1922, only two of these factories in Vladivostok represented the shipyard base of the Far East [5].

Nowadays, the Russian Far East shipbuilding industry is a set of enterprises and organizations working in the shipbuilding and ship repair sub-sectors, shipbuilding and 
electrical engineering, and marine instrumentation. Shipbuilding mainly determines the state national security in all spheres of maritime activities in Russia's Far East, including defense, transport, food, energy and technology. Shipbuilding has a multiplier effect, influence on the development of technology and production in related industries and services.

The Far Eastern shipbuilding industry in the Soviet period, like the entire state economy, functioned in fairly specific conditions of state administration and protectionism. In these conditions, the industry practically lacked internal incentives for systemic structural and innovative transformations. The functioning of the industrial enterprises of the Far East was characterized by the underdevelopment of pro-industrial and information ties, which hampered the improvement of the structure, development of their specialization and cooperation, and scientific support for the industry. In particular, ship-repair enterprises, which often existed as auxiliary production of certain shipowners, lagged far behind in technical development from shipbuilding enterprises of the corresponding specialization. As early as the 1970s and 1980s, attempts were made to introduce schemes of interdepartmental specialization and co-operation of shipbuilding and ship repair enterprises, coordination of research, design and technological works. However, these schemes, for the main part, were not implemented due to the prevalence of departmental interests [6]. In the period of transition to the market, the problems of shipbuilding and ship repair in the Far East were especially acute. The industry's stagnation factors were: the state's refusal from protectionism; lack of market competitive advantages; strengthening the impact of rising costs; liberalization of the external economic sphere; the international competition strengthening in this connection.

Table 1 - Characteristics of national shipbuilding support measures

\begin{tabular}{|c|c|c|c|c|c|}
\hline Country & $\begin{array}{l}\text { Shipbuilding } \\
\text { dotation }\end{array}$ & $\begin{array}{l}\text { Technical re- } \\
\text { equipment } \\
\text { support }\end{array}$ & $\begin{array}{l}\text { Tax and } \\
\text { customs } \\
\text { privileges }\end{array}$ & Preferential lending & $\begin{array}{c}\mathrm{R \& D} \\
\text { assistance }\end{array}$ \\
\hline Germany & + & + & + & \multirow{4}{*}{$\begin{array}{l}\text { OECD conditions: } \\
\text { loan - up to } 80 \% \\
\text { The loan term is } 10 \\
\text { years, interest rates } \\
\text { are not more than } 6 \% \\
\text { Tax benefits to the } \\
\text { German } \\
\text { superintendents } 300 \\
\text { million euros }\end{array}$} & \multirow{4}{*}{$\begin{array}{c}\text { About } 10 \% \text { of the annual } \\
\text { turnover of the shipbuilding } \\
\text { enterprises are directed to } \\
\text { R\&D. }\end{array}$} \\
\hline Italy & + & + & + & & \\
\hline Netherlands & + & + & + & & \\
\hline Finland & + & + & + & & \\
\hline USA & + & + & - & $\begin{array}{c}\text { Loan }-87,5 \% \text { of the } \\
\text { vessel price } \\
\text { Term - } 25 \text { years } \\
\end{array}$ & $\begin{array}{c}\text { Annual deductions for } \\
\text { defense research and } \\
\text { development }\end{array}$ \\
\hline $\begin{array}{l}\text { South } \\
\text { Korea }\end{array}$ & + & + & + & $\begin{array}{c}\text { OECD conditions, the } \\
\text { period is extended to } \\
13 \text { years }\end{array}$ & \multirow{2}{*}{$\begin{array}{l}\text { Up to } 50 \% \text { the of research } \\
\text { and development cost in the } \\
\text { area of shipbuilding - the } \\
\text { state own. In Korea, about } \\
250 \text { million dollars a year }\end{array}$} \\
\hline Japan & + & + & - & $\begin{array}{c}\text { Loan }-60-80 \% \text { of the } \\
\text { vessel value } \\
\text { Term } 10-15 \text { years at } \\
5-8 \% \text { per annum }\end{array}$ & \\
\hline China & + & + & + & $\begin{array}{l}\text { It is made by the } \\
\text { export-import bank of } \\
\text { the country }\end{array}$ & $\begin{array}{c}\text { R\&D is } 100 \% \text { financed by } \\
\text { the state }\end{array}$ \\
\hline
\end{tabular}

Source: compiled by the author [7].

Analysis of foreign countries experience shows that the creation of competitive advantages in the shipbuilding industry is largely ensured by the state, especially at the stages of initial development or recovery from the crisis periods in the country's economy. Over the past decades, in every country, comprehensive programs have been implemented to support the shipbuilding industry. The main measures for state support of national shipbuilding are reflected in Table 1. 
The lack of competition and shipbuilding products monopolization did not contribute to the development of new ship designs, the use of new technical solutions for their creation, and the creation and application of new, modern equipment-compliant equipment. After abandoning centralized planning and state budget financing, in connection with the transition to a market economy, domestic shipbuilding enterprises have faced the reality: the industry is not simply uncompetitive in the world market, but cannot even provide domestic demand for its products. The product policy shortcomings, the unbalanced structure of orders, the suboptimal enterprises production structure and the insufficient utilization of production capacities, as well as the qualified personnel shortage, were the main reasons for the unsatisfactory state of the industry.

Russian shipbuilding development programs, in general, limited by organizational measures, while more specific and effective instruments for increasing competitiveness should be sought.

Calculations show that the Republic of Korea and China have become quite a serious factor, which prevents the opportunities of the Far Eastern shipbuilding and ship repair enterprises to meet the needs of Russian enterprises. For example, the negative impact on the shipbuilding industry of foreign economic competition manifested itself in the almost complete cessation of production in the Far East of ships for the fishing industry. Shipbuilding enterprises that previously had a regional sales market reduced production tenfold, in particular for the following reason: relatively high production efficiency in the fish industry, with the shadow economy predominance in it and the possibility of leaving currency for abroad, predetermined the preference in large-scale purchases abroad of fishing vessels [8]. The decrease in capacity utilization has further strengthened the impact of the welfare factor. Almost all Far Eastern enterprises were in a difficult financial situation. And if the proproductive potential in the 90 s was preserved to some extent, the staffing problem was aggravated to the limit. This was affected by the low prestige of shipbuilders and ship repairmen labor for youth and the destruction of the workers preparation system in the basic specialties. In such economic conditions, all Far Eastern shipbuilding and ship repair enterprises worked.

In the way, the fundamental reasons determined the general trend of stagnation in the industry during the $90 \mathrm{~s}$ and mostly 2000s were: lack of market advantages for each enterprises in comparison with the same ones located in other regions of the country and abroad; lack of organizational and financial prerequisites for the introduction of innovations in the industry enterprises as a way of obtaining rent for the novelty of products and its scienceintensive nature; complexity of the formation of «new» management in the conditions of a mass change of the owners of enterprises.

In 2006-2008, a slow recovery of production began at the long-shipyard shipbuilding enterprises that retained their production base, which could find a niche in the domestic and foreign markets, which received state-of-the-art orders from the state. Institutional basis was the adoption of state program acts [9]. The «Strategy for the development of the shipbuilding industry in the period up to 2020 and for the future» [10] and the Federal Target Program «Development of civil marine equipment» for 2009-2016 were developed and approved [11].

By now, eight integrated structures have been created in the industry. The main one is OJSC United Shipbuilding Corporation, which included almost all leading design bureaus and largest plants [12]. The building of the State Scientific Center of the Russian Federation is being finalized on the basis of FSUE CRI named by acad. A.N. Krylov, which is the leading scientific organization of the industry and has a status that is determined by the scientific qualifications of the scientists and specialists of the institute that have established their own scientific schools universally recognized at the world level, as well as the technical state and uniqueness of the experimental base. The main experimental base in the field of marine technologies is concentrated in it.

Order of the Ministry of Industry and Trade of Russia of August 29, 2008, No. 112 approved the "Comprehensive Action Plan for the Implementation of the Strategy for the Development of the Shipbuilding Industry for the Period to 2020 and for the Future». The scientific and industrial potential development and the scientific reserve creation for the 
revival of the Russian shipbuilding industry was launched. This made it possible to significantly improve the situation of the industry and reduce the backlog rate in scientific and technological development from the leading maritime powers. The state program of the Russian Federation «Development of shipbuilding for 2013-2030» has been adopted.

Several years ago, the project for the formation of the Far Eastern Center for Shipbuilding and Ship Repair (DTSS) is being implemented. Now it is a subsidiary of the state holding United Shipbuilding Corporation (USC), the decree on the formation of which was signed by the Russian president in March 2007. DTSS unites the largest profile enterprises of the region and includes shipbuilding and ship repair plants in the Far Eastern Federal District, including Kamchatka, Khabarovsk and Primorsky Krai. This enterprise solves the problems of state importance, related to the preservation and development of the scientific and industrial potential of the defense industry complex, and directs its efforts to concentrate intellectual, industrial and financial resources in the implementation of projects for the construction of ships and marine equipment for the development of the Russian shelf. It consists of the following 8 shipbuilding and ship repair enterprises that ensure the state interests of the fleet in the Far East:

1. JSC «Ship repair center «Dalzavod», Vladivostok. The main activity of the enterprise is ship repair and other related works for the Pacific Fleet.

2. OOO Zvezda - DSME, Vladivostok. The enterprise was created to implement the project of building a shipyard in the southern part of Bolshoy Kamen, Primorsky Krai.

3. OJSC Vostok-Raffles, Vladivostok, a joint venture with the Singapore company CIMC Raffles Offshore (Singapore).

4. OJSC «92 Orders of the Red Banner of Labor ship repair plant», Vla-divostok. The main activity of the plant is the repair of military ships of the Pacific Fleet.

5. Open Society «Far East factory «The Star», the Big Stone of Primorye Territory. It is the leading company for the repair of submarines of the Pacific Fleet and the only one in the Far East that specializes in the repair, re-equipment and modernization of ships of nuclear submarine missile carriers.

6. JSC «Khabarovsk Shipbuilding Plant», Khabarovsk. The enterprise is one of the largest shipbuilding enterprises of the Far East. OAO KhSZ specializes in the construction of ships and boats, including those with dynamic support principles, for the Navy and vessels of various civilian classes.

7. OJSC Amur Shipyard, Komsomolsk-on-Amur, Khabarovsk Territory. This is a fullfledged shipbuilding enterprise that possesses the necessary production capacities and technologies for the construction of ships and ships of military and civilian use with a displacement of up to 25 thousand tons.

8. OJSC «North-Eastern Repair Center», Vilyuchinsk, Kamchatka Territory. The enterprise specializes in the repair and utilization of weapons and equipment of the Navy in the northeast of Russia.

In 2015, the United Shipbuilding Corporation transferred a controlling stake in the Far East Shipbuilding and Ship Repair Center to the joint venture Contemporary Shipbuilding Technology (CTC), which on an equal footing belongs to Rosneft and Gazprombank [13].

In general, it can be stated that this holding is focused on fulfilling the tasks of the system of increasing market competitiveness far from the organization. It would be more expedient to include all enterprises of the shipbuilding industry of the Far Eastern region in the production complex, which is prioritized by the task of ensuring national and international competitiveness, not only in the military, but primarily in civil shipbuilding and ship repair. The figure shows a scheme for the formation of a ship building and ship repairing production complex that unites specialized enterprises in the production of specific types of products (vessels of a certain production purpose) and technological specialization [5].

It should be noted that even taking into account the implementation of the measures of the said state programs, it is only that when achieving an acceptable competitiveness of shipbuilding, targeted and integrated planning and management of development in the industry in the ten-year perspective, it is possible to solve the problem only by returning growing customers in the country. To date, only the first steps have been taken to revitalize 
civil shipbuilding in the Far East: the launch of the production of medium-class fishing vessels, ice-resistant platforms, waterflooding modules for oil and gas on the Sakhalin shelf, construction of double-hulled tankers of increased strength, package carriers and timber carriers, ships for transporting chemicals and cleaning contaminated water.

According to one of the most authoritative experts on the problems of competitiveness, M. Porter, the main unit of international competition at the present stage is not the country, but the industry. The specificity of various industries does not imply the universalization of the format of competition, which leads to the multiplicity of its forms. But four classical elements still remain the common determinants national industry success in the international competition: 1) strategic flexibility and market advantages of the industry companies; 2) the presence of a developed and differentiated demand from the consumers of the industry; 3 ) the existence of developed supporting supplier industries; 4) the quality of the economic environment, largely dependent on the regulatory role of the state. Usually these conditions are realized systematically within the framework of an industry complex (or cluster). Cluster approach significantly affects the strategies of companies and own-to economic policy and the quality of the economic environment [14].

The experience of many countries shows that the creation of competitive advantages in shipbuilding is provided largely by the state, especially at the stages of initial development or recovery from crisis periods. Since the main competition for Far Eastern shipbuilding enterprises is made by the profile enterprises of the PRC and the Republic of Korea, we will name some measures of state support in these countries. During the last decades in each country complex programs of stimulating the shipbuilding industry are being implemented. Specific forms and mechanisms for supporting shipbuilding include the following: participation in the management of the restructuring and modernization of the fleet (Republic of Korea); regulation of the price of steel and ship equipment (PRC); state guarantees for loans to shipbuilders (PRC, Republic of Korea); reduction or cancellation of customs duties on the import of ship equipment (China); concessional lending up to $80 \%$ of the value of the vessel for 10-13 years, including a grace period equal to $1 / 3$ of the repayment time of the loan in foreign currency (Republic of Korea); customs duties on imported ship equipment (PRC) were abolished [7].

Nevertheless, the services that Korean and Chinese shipbuilders offer to international consumers are more of a set of values of the differentiation factor, rather than minimizing costs. These factors are often more important for the owners, since they allow them to reduce their direct costs. Such factors of differentiation include: reduction of the idle time of vessels, necessary and sufficient quality of work, reduction of the risk of costs for repairing the marriage, reduction of the need for input control, flexible financial terms of payments and settlements. The listed advantages of differentiation, as a rule, exceed, as a rule, the advantages associated with the cost of services, although the comparative cost of ship building and ship repairing services can not but matter to the shipowners. Nevertheless, in the implementation of the re-shaping of the Far Eastern shipbuilding complex and systemic links in the industry, it should be more focused not on minimizing costs, but on the opportunities for providing customers with a differentiated and high-quality service.

The last few years have been characterized by a large number of events aimed at developing shipbuilding in Russia and increasing its competitiveness. First, the «Strategy for the Development of the Shipbuilding Industry for the Period to 2020 and Further Prospects» was approved. The main objective of this strategy was to create a new competitive image of the shipbuilding industry based on the scientific and technical potential development, production capacities optimization, modernization and technical re-equipment, perfection of the regulatory framework to fully meet the needs of the state and business in modern shipbuilding products.

Secondly, «The Federal Program for the Development of Civilian Marine Equipment for the period 2009-2016» was prepared and approved, aimed at developing domestic scientific, technical and project potential and creating conditions for the production of competitive civil marine equipment that would fundamentally change the strategic competitive position civil shipbuilding of Russia and the conquest of the global sales market significant share by 2016 . 
In total, the Program provides for financing in the amount of about 140 billion rubles, including 90 billion rubles from the federal budget, 50 billion rubles from extra-budgetary sources.

Thirdly, in accordance with the Presidential Decree of March 21, 2007, «United Shipbuilding Corporation» was formed, which includes three territorial sub-holdings (western, northern and eastern) [12]. "Far East Center for Shipbuilding and Shiprepairing» is a subsidiary of the state holding "United Shipbuilding Corporation» (USC), whose edict was signed by the Russian president on March 21, 2007. DTSS unites the largest region profile enterprises and includes shipbuilding and ship-repair factories in the Far Eastern Federal District, including Kamchatka, Khabarovsk and Primorye.

Conclusion. Unfortunately, Russian shipbuilding development programs are still limited to organizational measures, although more specific tools are needed to increase the competitiveness of the industry. With a difference in the scale, forms and methods of supporting shipbuilding, many of the components are identical: direct subsidization of the construction of ships, provision of facilitated conditions for lending and tax relief, as well as financial assistance in the modernization and restructuring of shipyards, $R \& D$, state orders for the construction of civil vessels at national shipyards, cancellation of debts, and so on. The main purpose is to enable national enterprises to compete successfully with foreign companies at the expense of a relatively low level of prices for built vessels. In general, it can be concluded that in the context of the international competitiveness of the shipbuilding industry of the Russian Far East, in order to form and develop market competitive advantages of regional enterprises, more complex and concrete measures are needed both at the level of state support of the sector (at the macro level) and at level of the industry complex (at the micro level).

\section{REFERENCES}

1. Analysis of the civil shipbuilding market in Russa (2016) Annual report [Electronic resource]// Official site of RBC, URL: http://marketing.rbc.ru/research/27219

2. The Soviet Union in the mid-1950s - early 1960s. State and socio-political development of the USSR in the mid-1950s and early 1960s [Electronic resource]// Official site of NAROD, URL: http://aleho.narod.ru/eng/book2/ch21.htm

3. Gladun V.I. (1978) Features of the general scheme for the development of ship repair / / Me-thodological issues of the ocean economy study. Vladivostok.

4. United Shipbuilding Company for more than three years, but the results of its work are not impressive (2011) [Electronic resource]// Official site of Russian Shipbuilding Portal, URL: http: // shipbuilding .ru/rus/articles/DB-ROSS/

5. Osipov V.A. (2003) Efficiency of machine-building production: textbook. Vladivostok: Publ. house FESTU. 295 p.

6. Nedelko Yu.I., Korovin B.V. (1974) Actual issues of deepening specialization in the ship repair industry of the Far East // Issues of the Far East Economy №.2. - P. 12-24

7. World shipbuilding market. Fishing fleet segment (2014) [Electronic resource] // Official site of Russian pelagelic research company, URL: http://ruspelagic.ru/mirovoy_sudostroitelnyy_rynok._seg

8. Ilyinikh L.V. (2016) Far East: Chemicalization as driver of the economic growth of the macro-region [Electronic resource]// Official site of Chemical Industry Bulletin NIITEKHIM MOSCOW, URL: http://vestkhimprom.ru/posts/dalnij-vostok-khimizatsiya-kak-drajverekonomicheskogo-rosta-makroregiona

9. Shamray F.A. (2011) Questions of ensuring the competitiveness of shipbuilding // Information Marine Journal. № 1 (11) - pp. 87-99

10. Russian Federal Program «The Strategy of the Shipbuilding Industry Development for the Period to 2020 and Further Prospects» approved by Order of the Ministry of Industry and Energy of Russia of September 6, 2007 No. 354 [Electronic Resource] // Official site of «ConsultantPlus», URL: http://www.consultant.ru/document/cons_doc_LAW_99375/ 
11. Decree of the Russian Federation Government "On the Federal Target Program «Development of Civil Marine Equipment for 2009-2016» February 21, 2008 No. 103 (Edited on December 19, 2015) [Electronic Resource] // Official site of "ConsultantPlus», URL: http://www.consultant.ru/document/cons_doc_LAW_75828/

12. Decree of the President of the Russian Federation «About Open Joint-Stock Company United Shipbuilding Corporation» March 21, 2007 No. 394 [Electronic Resource] // Official site of Kremlin, URL: http://kremlin.ru/acts/bank/25217

13. OSK has transferred a controlling stake to the consortium with the participation of Rosneft (2015) [Electronic Resource] // Official site of Oil\&GasCapital, URL: https://oilcapital.ru/news/companies/14-07-2015/osk-peredala-kontrolnyy-paketdtsss-konsortsiumu-s-uchastiem-rosnefti.

14. Porter M. (2011) Competitive Strategy: The Technique of Analysis of Industries and Competitors / Per. with English. I. Minervina; - Moscow: Publ. house «Alpina Pablisher». $454 \mathrm{p}$. 